Cell-Based Therapy for Retinal Degenerative Disease 


\section{Developments in Ophthalmology}

Vol. 53

Series Editor

F. Bandello Milan 


\section{Cell-Based Therapy for Retinal Degenerative Disease}

Volume Editors

Ricardo P. Casaroli-Marano Barcelona

Marco A. Zarbin Newark, N.J.

55 figures, 41 in color, and 6 tables, 2014 
Ricardo P. Casaroli-Marano

Instituto Clínic de Oftalmología

Calle Sabino de Arana 1

ES-08028 Barcelona (Spain)
Marco A. Zarbin

Institute of Ophthalmology and Visual Science

Rutgers-New Jersey Medical School

Rutgers University

Room 6155, Doctors Office Center

90 Bergen Street

Newark, NJ 07103 (USA)

Library of Congress Cataloging-in-Publication Data

Cell-based therapy for retinal degenerative disease / volume editors, Ricardo P. Casaroli-Marano, Marco A. Zarbin.

p. ; cm. -- (Developments in ophthalmology, ISSN 0250-3751; vol. 53)

Includes bibliographical references and index.

ISBN 978-3-318-02584-2 (hard cover : alk. paper) -- ISBN 978-3-318-02585-9

(e-ISBN)

I. Casaroli-Marano, Ricardo Pedro, editor of compilation. II. Zarbin,

Marco A., editor of compilation. III. Series: Developments in ophthalmology;

v. $53.0250-3751$

[DNLM: 1. Retinal Degeneration--therapy. 2. Stem Cell Transplantation.

W1 DE998NG v.53 2014 / WW 270]

RE661.D3

$617.7^{\prime} 35--d c 3$

2014004771

Bibliographic Indices. This publication is listed in bibliographic services, including Current Contents ${ }^{\circledR}$ and Index Medicus..

Disclaimer. The statements, opinions and data contained in this publication are solely those of the individual authors and contributors and not of the publisher and the editor(s). The appearance of advertisements in the book is not a warranty, endorsement, or approval of the products or services advertised or of their effectiveness, quality or safety. The publisher and the editor(s) disclaim responsibility for any injury to persons or property resulting from any ideas, methods, instructions or products referred to in the content or advertisements.

Drug Dosage. The authors and the publisher have exerted every effort to ensure that drug selection and dosage set forth in this text are in accord with current recommendations and practice at the time of publication. However, in view of ongoing research, changes in government regulations, and the constant flow of information relating to drug therapy and drug reactions, the reader is urged to check the package insert for each drug for any change in indications and dosage and for added warnings and precautions. This is particularly important when the recommended agent is a new and/or infrequently employed drug.

All rights reserved. No part of this publication may be translated into other languages, reproduced or utilized in any form or by any means electronic or mechanical, including photocopying, recording, microcopying, or by any information storage and retrieval system, without permission in writing from the publisher.

(c) Copyright 2014 by S. Karger AG, P.O. Box, CH-4009 Basel (Switzerland)

www.karger.com

Printed in Germany on acid-free paper by (ISO 9706) by Kraft Druck, Ettlingen

ISSN 0250-3751

e-ISSN 1662-2790

ISBN 978-3-318-02584-2

e-ISBN 978-3-318-02585-9 


\section{Contents}

VII List of Contributors

XI Preface

Casaroli-Marano, R.P. (Barcelona); Zarbin, M.A. (Newark, N.J.)

1 Age-Related Macular Degeneration: Clinical Findings, Histopathology and Imaging Techniques

Zarbin, M.A. (Newark, N.J.); Casaroli-Marano, R.P. (Barcelona); Rosenfeld, P.J. (Miami, Fla.)

33 General Pathophysiology in Retinal Degeneration

Wert, K.J. (New York, N.Y.); Lin, J.H. (La Jolla, Calif.);Tsang, S.H. (New York, N.Y.)

44 Juvenile-Onset Macular Degeneration and Allied Disorders

North, V. (New York, N.Y.); Gelman, R. (Los Angeles, Calif.); Tsang, S.H. (New York, N.Y.)

53 Diagnosis and Complementary Examinations

Menghini, M.; Duncan, J.L. (San Francisco, Calif.)

70 Stem Cells for Retinal Repair

Stern, J.; Temple, S. (Rensselaer, N.Y.)

81 Differentiation of Pluripotent Stem Cells into Retinal Pigmented Epithelium

Croze, R.H.; Clegg, D.O. (Santa Barbara, Calif.)

97 Neural Retinal Regeneration with Pluripotent Stem Cells

Ramsden, C.M.; Powner, M.B.; Carr, A.-J.F.; Smart, M.J.K.; da Cruz, L. (London);

Coffey, P.J. (London/Santa Barbara, Calif.)

111 Stem Cells, Retinal Ganglion Cells and Glaucoma

Sluch, V.M. (Baltimore, Md.); Zack, D.J. (Baltimore, Md./Paris)

122 Stem Cells: Immunology and Immunomodulation

Tena, A.; Sachs, D.H. (Boston, Mass.)

133 Biochemical Restoration of Aged Human Bruch's Membrane: Experimental Studies to Improve Retinal Pigment Epithelium Transplant Survival and Differentiation

Sugino, I.K.; Sun, Q.; Cheewatrakoolpong, N. (Newark, N.J.); Malcuit, C. (Kent, Ohio);

Zarbin, M.A. (Newark, N.J.)

143 Approaches to Cell Delivery: Substrates and Scaffolds for Cell Therapy Kundu, J.; Michaelson, A.; Baranov, P.; Young, M.J.; Carrier, R.L. (Boston, Mass.)

155 Microdevice-Based Cell Therapy for Age-Related Macular Degeneration Lu, B.; Tai, Y.-C. (Pasadena, Calif.); Humayun, M.S. (Los Angeles, Calif.) 
167 Cell and Gene Therapy

Rao, R.C.; Zacks, D.N. (Ann Arbor, Mich.)

178 Cellular Manufacturing for Clinical Applications

Sheu, J. (Sacramento, Calif.); Klassen, H. (Irvine, Calif.); Bauer, G. (Sacramento, Calif.)

189 Regulatory Issues in Cell-Based Therapy for Clinical Purposes

Casaroli-Marano, R.P.; Tabera, J.; Vilarrodona, A.; Trias, E. (Barcelona)

201 Subject Index 


\section{List of Contributors}

\section{Petr Baranov}

Schepens Eye Research Institute

An affiliate of Harvard Medical School

Boston, MA 02114 (USA)

E-Mail Petr_Baranov@meei.harvard.edu

\section{Gerhard Bauer}

Institute for Regenerative Cures

University of California Davis School of Medicine

Sacramento, CA 95817 (USA)

E-Mail gerhard.bauer@ucdmc.ucdavis.edu

\section{Amanda-Jayne F. Carr}

The London Project to Cure Blindness

Division of ORBIT

Institute of Ophthalmology, University College London

11-43 Bath Street

London EC1V 9EL (UK)

E-Mail a.carr@ucl.ac.uk

\section{Rebecca L. Carrier}

Chemical Engineering

Northeastern University 360 Huntington Avenue Boston, MA 02115 (USA)

E-Mail r.carrier@neu.edu

\section{Ricardo P. Casaroli-Marano}

Instituto Clínic de Oftalmología

Calle Sabino de Arana 1

ES-08028 Barcelona (Spain)

E-Mail rcasaroli@ub.edu

\section{Noounanong Cheewatrakoolpong}

Institute of Ophthalmology and Visual Science

Rutgers-New Jersey Medical School

Rutgers University

Room 6155, Doctors Office Center

90 Bergen Street

Newark, NJ 07103 (USA)

E-Mail cheewano@njms.rutgers.edu

\section{Dennis O. Clegg}

Center for Stem Cell Biology and Engineering Neuroscience Research Institute, University of California Santa Barbara, CA 93106 (USA)

E-Mail clegg@lifesci.ucsb.edu

\section{Peter J. Coffey}

The London Project to Cure Blindness,

Division of ORBIT

Institute of Ophthalmology, University College London

11-43 Bath Street

London EC1V 9EL (UK)

E-Mail p.coffey@ucl.ac.uk

\section{Roxanne H. Croze}

Center for Stem Cell Biology and Engineering

Neuroscience Research Institute, University of California

Santa Barbara, CA 93106 (USA)

E-Mail croze@lifesci.ucsb.edu

\section{Lyndon da Cruz}

NIHR Biomedical Research Centre at Moorfields Eye Hospital NHS Foundation Trust and

UCL Institute of Ophthalmology

London EC1V 2PD UK

E-Mail Lyndon.daCruz@moorfields.nhs.uk 
Jacque L. Duncan

10 Koret Way, K129

San Francisco, CA 94143-0730 (USA)

E-Mail duncanj@vision.ucsf.edu

\section{Rony Gelman}

Department of Ophthalmology

University of Southern California Eye Institute

University of Southern California

1450 San Pablo Street

Los Angeles, CA 90033 (USA)

E-Mail rgelman@usc.edu

\section{Mark S. Humayun}

Doheny Retina Institute

University of Southern California

1355 San Pablo St., DVRC 119

Los Angeles, CA 90033 (USA)

E-Mail humayun@usc.edu

\section{Henry Klassen}

Gavin Herbert Eye Institute and

Stem Cell Research Center

University of California, Irvine

Irvine, CA 92697 (USA)

E-Mail hklassen@uci.edu

\section{Joydip Kundu}

Chemical Engineering

Northeastern University

360 Huntington Avenue

Boston, MA 02115 (USA)

E-Mail j.kundu@neu.edu

\section{Jonathan H. Lin}

Shiley Eye Center

Department of Pathology

University of California San Diego

La Jolla, CA 92093 (USA)

E-Mail JLin@ucsd.edu

\section{Bo Lu}

Berkeley Lights, Inc.

5885 Hollis St., Suite 370

Emeryville, CA 94608 (USA)

E-Mail lubomems@gmail.com

\section{Christopher Malcuit}

Department of Biological Sciences

Kent State University

Kent, OH 44242 (USA)

E-Mailcmalcuit@kent.edu

\section{Moreno Menghini}

Department of Ophthalmology

University of California, San Francisco

400 Parnassus

San Francisco, CA 94143 (USA)

E-Mail moreno.menghini@me.com

\section{Andrew Michaelson}

Chemical Engineering

Northeastern University

360 Huntington Avenue

Boston, MA 02115 (USA)

E-Mailmichaelson.a@husky.neu.edu

\section{Victoria North}

College of Physicians and Surgeons

Columbia University

630 West 168th Street

New York, NY 10032 (USA)

E-Mail vsn2104@mail.cumc.columbia.edu

Michael B. Powner

The London Project to Cure Blindness

Division of ORBIT

Institute of Ophthalmology, University College London

11-43 Bath Street

London EC1V 9EL (UK)

E-Mailm.powner@ucl.ac.uk

\section{Conor M. Ramsden}

The London Project to Cure Blindness

Division of ORBIT

Institute of Ophthalmology

University College London

11-43 Bath Street

London EC1V 9EL (UK)

E-Mail conor.ramsden.09@ucl.ac.uk 


\section{Rajesh C. Rao}

Department of Ophthalmology \& Visual Sciences

W.K. Kellogg Eye Center

Department of Pathology

University of Michigan Medical School

1000 Wall St.

Ann Arbor, MI 48105 (USA)

E-Mail rajeshr@med.umich.edu

\section{Philip J. Rosenfeld}

Bascom Palmer Eye Institute

900 NW 17th St.

Miami, 33136 (USA)

E-Mail prosenfeld@med.miami.edu

\section{David H. Sachs}

Transplantation Biology Research Center

Harvard Medical School and

Massachusetts General Hospital

149 13th Street, Suite 9019

Boston, MA 02129 (USA)

E-Mail david.sachs@tbrc.mgh.harvard.edu

\section{Jonathan Sheu}

Institute for Regenerative Cures

University of California Davis School of Medicine

Sacramento, CA 95817 (USA)

E-Mail jonathan.sheu@ucdmc.ucdavis.edu

\section{Valentin M. Sluch}

Biochemistry, Cellular and

Molecular Biology Graduate Program

Johns Hopkins University School of Medicine

Wilmer Eye Institute

400 N. Broadway, Smith Building 3001-K

Baltimore, MD 21287 (USA)

E-Mail vsluch1@jhmi.edu

\section{Matthew J.K. Smart}

The London Project to Cure Blindness

Division of ORBIT

Institute of Ophthalmology, University College London

11-43 Bath Street

London EC1V 9EL (UK)

E-Mail matthew.smart@ucl.ac.uk

\section{Jeffrey Stern}

Neural Stem Cell Institute

One Discovery Drive

Rensselaer, NY 12144 (USA)

E-Mail retina@nycap.rr.com

\section{llene K. Sugino}

Institute of Ophthalmology and Visual Science Rutgers-New Jersey Medical School

Rutgers University

Room 6155, Doctors Office Center

90 Bergen Street

Newark, NJ 07103 (USA)

E-Mail suginoik@njms.rutgers.edu

\section{Qian Sun}

Institute of Ophthalmology and Visual Science Rutgers-New Jersey Medical School

Rutgers University

Room 6155, Doctors Office Center

90 Bergen Street

Newark, NJ 07103 (USA)

E-Mail sunqi@njms.rutgers.edu

\section{Jaime Tabera}

Transplant Services Foundation (TSF)

Hospital Clínic de Barcelona

ES-08036 Barcelona (Spain)

E-Mail JTABERA@clinic.ub.es

\section{Yu-Chong Tai}

Electrical Engineering

California Institute of Technology

1200 E. California Blvd

Pasadena, MC 136-93, CA 91125 (USA)

E-Mail yctai@caltech.edu

\section{Sally Temple}

Neural Stem Cell Institute

One Discovery Drive

Rensselaer, NY 12144 (USA)

E-Mail sallytemple@neuralsci.org

\section{Aseda Tena}

Transplantation Biology Research Center

Harvard Medical School and

Massachusetts General Hospital

149 13th Street, Suite 9019

Boston, MA 02129 (USA)

E-Mail Aseda.Tena@tbrc.mgh.harvard.edu

\section{Esteve Trias}

Transplant Services Foundation (TSF)

Hospital Clínic de Barcelona

ES-08036 Barcelona (Spain)

E-Mail ETRIAS@clinic.ub.es 


\section{Stephen H. Tsang}

Departments of Pathology \& Cell Biology and Ophthalmology

New York-Presbyterian/Columbia University

Medical Center

630 West 168th Street

New York, NY 10032 (USA)

E-Mail sht2@columbia.edu

\section{Anna Vilarrodona}

Transplant Services Foundation (TSF)

Hospital Clínic de Barcelona

ES-08036 Barcelona (Spain)

E-Mail AVILARRO@clinic.ub.es

\section{Katherine J. Wert}

The Whitehead Institute for Biomedical Research Jaenisch Laboratory

Nine Cambridge Center

Cambridge, MA 02142 (USA)

E-Mail wert.katherine@gmail.com

\section{Michael J. Young}

Schepens Eye Research Institute

An affiliate of Harvard Medical School

Boston, MA 02114 (USA)

E-Mail michael_young@meei.harvard.edu

\section{Donald J. Zack}

Ophthalmology, Wilmer Eye Institute Johns Hopkins University School of Medicine 400 N. Broadway, Smith Building 3029

Baltimore, MD 21287 (USA)

E-Mail dzack@jhmi.edu

\section{David N. Zacks}

Department of Ophthalmology \& Visual Sciences W.K. Kellogg Eye Center

University of Michigan Medical School 1000 Wall St.

Ann Arbor, MI 48105 (USA)

E-Mail davzacks@umich.edu

\section{Marco A. Zarbin}

Institute of Ophthalmology and Visual Science Rutgers-New Jersey Medical School

Rutgers University

Room 6155, Doctors Office Center

90 Bergen Street

Newark, NJ 07103 (USA)

E-Mail zarbin@earthlink.net 


\section{Preface}

Degenerative diseases of the retina and optic nerve (e.g. age-related macular degeneration (AMD), Stargardt disease, retinitis pigmentosa, and glaucoma) are major causes of blindness today. Because the most prevalent of these conditions are age-related (i.e. AMD, glaucoma), as life expectancy continues to increase, both in industrialized countries as well as in developing countries, the number of afflicted patients will grow during the 21 st century.

The final stages of these forms of blindness involve the degeneration and death of neurons (e.g. photoreceptors, retinal ganglion cells) and/or supportive cells (e.g. retinal pigment epithelium, choriocapillaris). However, with the advent of new approaches in the fields of molecular and cellular biology, genomics, and proteomics, different candidate genes and specific pathophysiological mechanisms responsible for some of the most important retinal and optic nerve degenerations have been identified. This information has advanced the development of innovative treatments involving gene replacement/repair, small molecules, antibodies, neurotrophic factors, and nutritional supplements. Unfortunately, currently available treatments for these conditions tend to work by retarding the progression of visual loss and do not restore lost vision in the long-term. Thus, a significant proportion of patients with degenerative retinal disease and glaucoma lose vision due to progressive neuron death and might benefit from cell replacement therapy.
The first reports of James Till and Ernest McCulloch concerning the presence of hematopoietic cells with characteristics of progenitor cells in the adult organism and the recent experiments of Kazutoshi Takahashi and Shinya Yamanaka, with generation of induced pluripotent stem cells from dermal murine fibroblasts, have generated great interest in cell-based therapy. The differentiation potential of embryonic stem cells and the apparent and unexpected recovery of stem cells from adult tissue allow us to imagine a hopeful future for a number of currently incurable degenerative diseases. The plasticity of stem cells confers upon them the capacity to reconstruct structures and damaged neurons in degenerative diseases of the central nervous system. Neuronal replacement, however, requires that the implanted cells not only survive after transplantation, but also establish appropriate synaptic connections and integrate with the surrounding tissue. Various cell types have been used for cell-based ocular therapy in preclinical models, including fetal or neonatal retinal neurons, progenitor cells from adult retina, corneal-scleral progenitor cells of the limbus, brain neuronal progenitors, pluripotent stem cells derived from bone marrow or adipose tissues, and embryonic stem cells. Differentiation of stem cells into various sorts of ocular cells (e.g. neurons, retinal pigment epithelium, Müller cells) establishes the possibility of their use for treatment in retinal degenerations such as AMD, Stargardt disease, retinitis pigmentosa, and glaucoma. 
Therapeutic cells can be delivered to the retina by various routes (e.g. intravenous, intravitreal, and subretinal injection) and organized in various ways (e.g. as a cell suspension, as an intact sheet, in association with carriers and biocompatible substrates). Once implanted, the cells can preserve and/or restore vision by fostering the survival of host cells through neurotrophic factor production or altering the extracellular environment in some way (termed 'rescue therapy'), as well as by replacing damaged tissues (termed 'replacement therapy'). Obstacles to successful rescue therapy include survival and appropriate differentiation of the transplanted cells. Obstacles to successful replacement therapy include migration/delivery to the appropriate extracellular location, establishment of appropriate synapses with host neurons, and survival and appropriate differentiation. Formation of appropriate synapses may be complicated by the fact that degenerating retina tends to undergo synaptic remodeling with formation of unconventional synaptic connections between neurons. Cell survival depends not only on appropriate environmental cues, which may be altered in a chronic disease associated with accumulation of abnormal extracellular material (e.g. AMD), but also, if allogeneic tissue is used, on immune tolerance by the host. Several clinical trials are underway to assess the safety and efficacy of cell therapy as a treatment for degenerative diseases of the retina and optic nerve, including 'rescue' as well as 'replacement' approaches. Mesenchymal stem cells, embryonic stem cells, and induced pluripotent stem cells are being deployed for this purpose.

This text on cell-based ocular therapy is the first of its kind. Herein, some of the leading authorities in the world explore applications of stem cell therapy to the treatment of major causes of blindness, including retinal degenerative diseases as well as glaucoma. The diagnostic approach to patients, general concepts of cell-based therapy, immunological considerations, approaches to cell delivery (including engineered scaffolds), com- bined cell and gene therapy, nanomedicine applications to cell therapy, and regulatory issues pertaining to cell manufacture and production are considered in detail. Physicians and business executives interested in understanding the potential applications of stem cell therapy to retinal degenerative disease and glaucoma will find this analysis of the potential value, current obstacles to progress, and review of manufacturing regulations of cell-based therapy for ocular disease to be helpful in judging the value of emerging technologies, the rationale for emerging clinical trials, and the optimal disease targets for cell-based ocular therapy. Ophthalmology traditionally has been a source of innovation in medicine. The first successful tissue transplant in humans (cornea), the first therapeutic application of lasers (for diabetes), the first randomized multicenter clinical trial (for diabetes), the first successful application of gene therapy (for Leber congenital amaurosis), and development of the first noninvasive imagining of neural tissue with histology level resolution all were conducted by ophthalmologists. We predict that the first successful application of stem cell therapy for neural disease will also occur in Ophthalmology.

We gratefully acknowledge our co-authors, whose excellence and generous contribution of time and effort made this text possible. We also thank the editorial team of Developments in Ophthalmology for their expert and constant support. We dedicate this book to our patients and to their families, whose courage and forbearance inspires us to work diligently to find ways to restore vision to the blind and visually impaired.

Ricardo P. Casaroli-Marano, Barcelona Marco A. Zarbin, Newark, N.J. 